INFO- 148

Primljeno/Received: 2019-09-15
UDK: $342.735: 7$

Pregledni rad/Authors Review

10.32914/mcpr.10.2.6

\title{
VERTIKALA ŽIVOTA ZA ŽIVOT NA SCENI Ilir Kerni, nacionalni prvak baleta HNK Zagreb
}

\author{
Slobodan Elezović \\ Hrvatsko komunikološko društvo, Zagreb, Hrvatska
}

\begin{abstract}
Sažetak
U svojoj 60. životnoj godini i s puna četiri desetljeća pripadanja umjetnosti, baletnoj umjetnosti kao najsloženijem i slojevitom plesno-scenskom umjetničkom izrazu, gospodin Ilir Kerni je, ukupnim svojim tvoračkim postignućima i razinama ostvarenja u svjetskim koordinatama, postao, prirodo, subjektom sustavnog pristupa i izabrane monografske građe kao poticaja za sve sustavnije i pažljivije pripadanje stvaralačkom životu i radu osobita čovjeka i Njegova svjetonazora s istaknutim estetskim koordinatama u pristupanju svojoj temeljnoj djelatnosti, plesno-scenskoj umjetnosti s rasponom njezinih stilova i obilatih izbora vrsta za uspješan start $i$ jamačne visove $u$ konačnici sustavnoga koreo-pedagoškog rada i izgradnje svake nove uloge, žarom debuta, svježinom i posvemašnošću elana, entuzijazma i punog kapaciteta u pristupu kao velikom jamcu za najviše domete i mogućnosti medjunarodnoga predstavljanja svojih kreacija diljem velikih zemalja i svjetskih umjetničkih scena $\mathrm{u}$ najvećim središtima baletne umjetnosti. Nastala fotomonografija je tek 'putokazni simbol' izraz naglasaka vrijednosti koje se kao uzor umijeća pripadanja izabranom poslu, pretvaraju u kategoriju najviše razine polazišne platforme za velike kreacije i, dostojno svemu tomu, mjesto u domaćoj i svjetskoj tvoračkoj umjetničkoj eliti.
\end{abstract}

Ključne riječi

Ilir Kerni, balet, umjetnost

\section{Ilir Kerni}

Ilir Kerni rođen je 18. svibnja 1959. godine u Tirani, Albanija. Na Baletnoj akademiji u Tirani završio je ples i baletnu pedagogiju. Od 1977. angažiran je u Nacionalnom kazalištu u Tirani, gdje je ubrzo stekao status prvaka baleta. Zahvaljujući petomjesečnoj stipendiji UNESCO-a, 1991. godine se usavršava u Operi u Strasbourgu i u pariškoj operi.
Od 1991. do 1993. angažiran je u baletnoj trupi Ballet du Rhin. Surađivao je s mnogim velikim koreografima poput Claudea Bromorcha, lve Kramara, Oscara Araiza, Bertranda D'Ata, Vasca Wellenkampa. Član Baleta HNK u Zagrebu postaje 1994. godine. Djeluje i kao baletni majstor. Od 2013 . do 2016. bio je intendant Albanskoga narodnog kazališta Opere i Baleta u Tirani. 

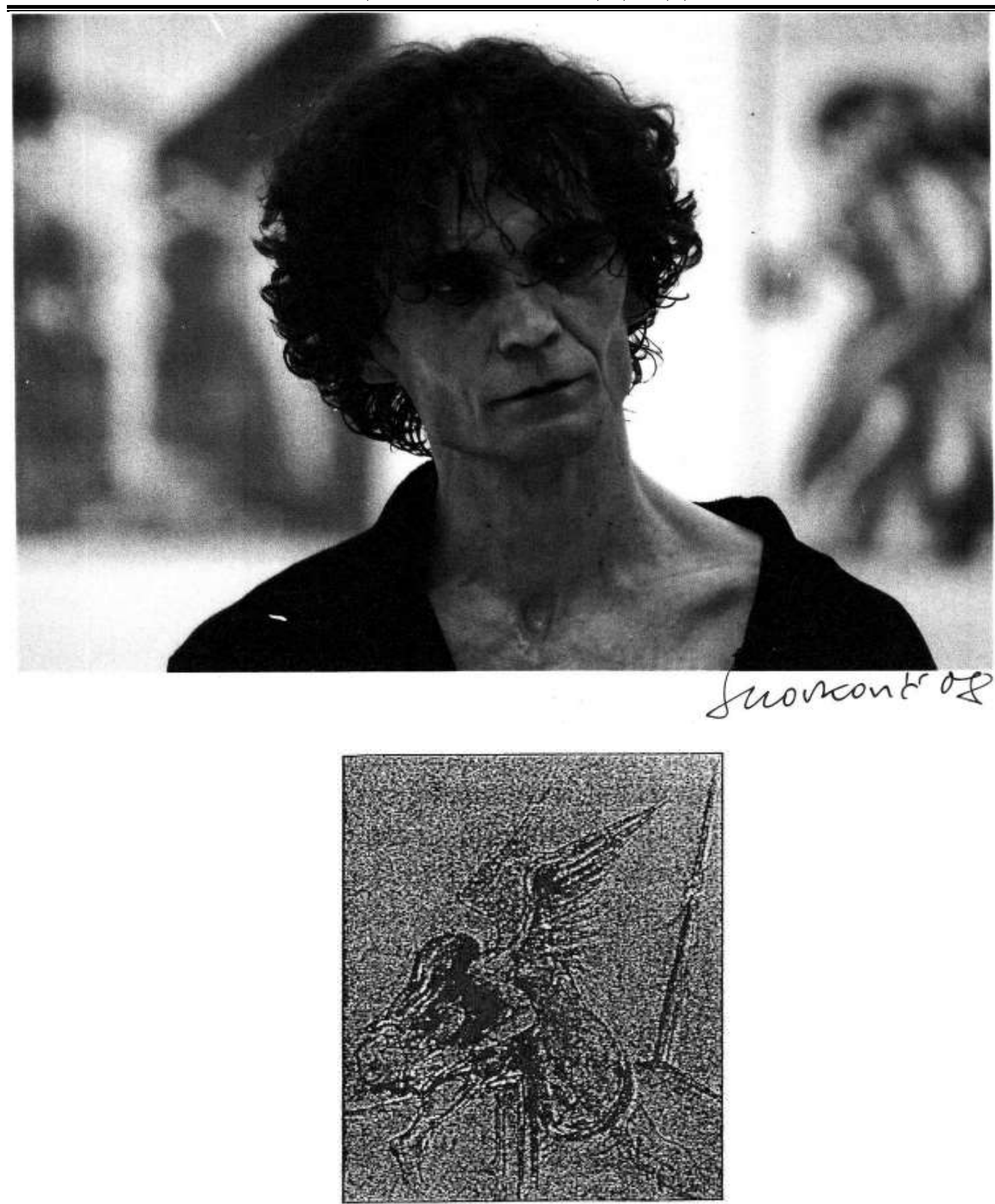

\section{Snaga i moć invencije i kreacija}

Pokret, inherentan prirodi čini svaki hip vremena drugačijim i afirmira spoznaju da nema dva istovjetna trenutka $\mathrm{u}$ tijeku vremena. To je snažan izazov čovjeku i njegovoj znatiželji da upoznaje svijet i njegove pojavnosti, da otkriva odjeke spoznatoga u sebi i transformira ih $\mathrm{u}$ odnose koji postaju izrazom osobnoga svjetonazora svakog pojedinca.

Oni pojedinci čiji je duh organiziran u harmoniji svih spoznajno-čulno-čuvstvenoISSN 1333-6371 racionalnih sposobnosti, stvaraju, tom osobnom harmonijom, široke temelje za veće opsege odjeka života i postaju ljudi viših i širih duhovnih „prostora“. Često ih nazivamo darovitim pojedincima koji svoje bogate prirodne temelje, uspiju li ih nadgraditi potrebitim znanjima, pretvaraju u obilata ishodišta mnogih inspiracija koje u područjima duhovnoga stvaranja stječu mogućnosti afirmacije kroz sustav umjetnosti ili znanosti, s aplikacijama u području one grane za koju se osjeti, unutarnjim imperativom, najjači afinitet. Svrstana iskustva iz područja znanosti su često lako prim- 
jenjiva u području autohotnog umjetničkog stvaralaštva, pa umjetnost postaje sve uplivnijim faktorom u čovjekovu životu. Ona, često, esencijalnim osvrtom na život i čovjekovu sudbinu, poručuje, osvaja, zanosi, potiče i obogaćuje, jače i brže od mnogih drugih izvora spoznaja i odnosa koje ukupno čovjekovo iskustvo sadrži i nudi.

Umjetnost, kao izraz više kategorije duha, predmnijeva njegovu metodičnost kao nužnu posljedicu prethodno shvaćene važnosti discipline, poglavito samodiscipline. Bez reda $u$ sebi nema uspješnog rada, pa što prije shvatimo tu istinu, ranije smo u prilici stići do točke uspješne individualne tvorbenosti, koja u slučaju visoke izričajne razine, može postati i kreacijom. Klasik umjetnosti riječi, Ivan Sergejevič Turgenjev, tvrdi da je život s umjetnošću kvalitetniji, jer ona pomaže da dobro bude bolje, a svako zlo lakše. Umjetnost se jedina bavi čovjekom i njegovom sudbinom $\mathrm{u}$ svim mogućim aspektima vrijednosti i značenja, pak je nezaobilaznom potrebom $\mathrm{u}$ procesu čovjekova odrastanja i sazrijevanja. Znanost, uopćeno rečeno, analizira, dok umjetnost sintetizira iskustva do pune i potpune "slike života“ i naznaka mogućnosti čovjeka kao subjekta života. Stoga je, neprijeporno, nezamjenljiva za uspješnu harmoniju svakog iole oduhovljenog pojedinca.

Pokret i kretnje, inherentni su prirodi i čovjeku kao njenom ekskluzivnom i elitnom subjektu. U sistematizaciji iskustava stvorenih i razvijenih vrsta umjetnosti, umjetnost pokreta, namijenjenog različitim zgodama, od čovjekova iskustva iz pradoba, s razlogom prima epitet najstarije. Stoga je njena bit posebnoga značenja.

Pokreti i ritmovi su esencija života. Pokreti oko nas, odjeci u nama i pokreti nas samih, duhovni i fizički, tek su segmenti sveukupnosti kretanja. Segmente spoznavati, miksirati i tvoriti slogove koji, u zakonitostima scenske umjetnosti vremena, mjesta i zbivanja, čarima „bengalske rasvjete" otkrivaju život u čovjeku i smisao života oko njega, znači supstancijalno skrbiti o čovjeku, njegovu

dostojanstvu i perspektivama. Iskustva čovjekove sudbine su pregolema, a umjetnost pridonosi svakoj novoj generaciji ljudi da se lakše i brže nađu i snađu, u sebi i oko sebe. Umjetnost pokreta, ritma i glazbe, su u tom procesu gotovo primame, po značenjima i radijusu upliva na čovjekovu osobnost.

Bit će razumljivo da je susret sa majstorom, štaviše velemajstorom, ovih primarnih vrsta, izvor posebnih, gotovo ekskluzivnih uzbuđenja koja u duhu rasplamsavaju i maštu, pa time obogaćuju iskustva do kategorije plemenitosti.

Ponude psihološke znanosti, dinamično i kvalitativno razvijene $\mathrm{u}$ ovome, XX. stoljeću, otkrivaju da je pokret najautohtoniji čovjekov iskaz njegovih „unutarnjih sadržaja”. Promatramo li čovjeka koji sâm kreče ulicom, možemo ne samo naslutiti, već i s više pouzdanosti prepoznati u kojoj je "boji” raspoloženja, prema vrsti, ritmu i kakvoći pokreta, od koraka, načina hoda, vrste kretanja torakalnim dijelom, motorikom ekstremiteta, detektira se čak i vrsta temperamenta, energetski „naboj” primjeren dobi osobe, pa nailazimo na žustre, živahne, vedre starije osobe ili pak trome, ulijenjene, "teške", načinom kretanja, mlade osobe, tim prije, ako su nezadovoljne odgođenim ili onemogućenim ispunjavanjem svojih ambicija ili bilo koje vrste svojih mladenačkih snova. Život ispunjen zadovoljstvom čini i starijeg čovjeka živahnih pokreta $\mathrm{u}$ ritmu naviknutih dinamika $\mathrm{u}$ životu i radu koji je rezultirao uspjesima i ispunjavanjem želja i očekivanja, postavljenih kao cilj matičnoga zalaganja i djelatnosti.

Sadržaj duha raspoloženja i stanja, imaju svoj puni ekvivalent $\mathrm{u}$ pokretu tijela, kao što se $\mathrm{i}$ vrste pratećih misli i čuvstava odzrcaljuju izrazom lica kao "najživljom scenom" čovjekovih duhovnih strujanja. Kret je temeljni znak svake vrste interpersonalne komunikacije, određuje na vrlo tankoćutan način smisao izgovorene riječi i usmjerava asocijativni tijek $\mathrm{u}$ razmišljanju sugovornika. Gesta, mimika, kretnje tijelom, poglavito rukama koje prate riječi, izričaje i razgovor u cjelini, pridonose slojevima smisla u mjeri koja neposredan susret osoba u komunikaciji čini nenadomjestivim, usprkos modernim tehničko-tehnološkim mogućnostima kojima se može uspješno komunicirati mnogim vrstama posredstava, pomoću vrlo sofisticiranih audio $i$ video instrumenata, sve obilatijim $u$ dinamici i uvjetima suvremenosti.

Pokret kao univerzalni fenomen, utkan u funkciju plesne umjetnosti kao jedne od scenskoizvedbenih vrsta $u$ tisućljetnom iskustvu teatra, znači mnogoslojnu podlogu za stvaranje kazališne predstave sa svim dramaturškim zakonitostima i zakonomjernostima kakve nalazimo u primjerima drame, kao književnoumjetničkog roda, razvijenog od dionizijskih svetkovina u doba antičke grčke epohe. Ples s atributima koji ga uznose do kategorije umjetnosti, i balet njena posebna vrsta, je kao scenski- 
uprizoreno zbivanje, tek posebna vrsta drame $\mathrm{u}$ kojoj se sve psihološke značajke protagonista, njihovi pokretački motivi, ideje kao impulsi za iskaz radnje, pa zaplet, kulminacija i rasplet, odvijaju prema svim vrijednostima dramsko-scenske umjetnosti razvijane tisućljećima.

Elementi koji određuju dramsko-scensko događanje polaze iz „svetoga kruga” pozornice na kojoj nastaju odnosi likova kao nositelja zbivanja koje se razvija nizom dramskih situacija s likovima kao njihovim tvorcima. Slijed dramskih situacija tvore tzv. kompoziciju zbivanja koja treba afirmirati put i uvjete afirmacije ideje protagonista i označavati vrste $i$ oblike njihove "sudbine" tj. pobjede ili poraza, o čemu ovisi značenje i vrijednost poruke djela.

Za indikaciju odnosa među likovima ne mora nužno biti pisani dijalog, jer je vrlo često pokret „baza” komunikacije iz koje se zaključuje o odnosima likova, često pouzdanije i suptilnije od uporabljenih riječi i njihovih značajki. Pokret često, eliptičnom sugestivnošću i jasnoćom, iskazuje karakterološke vrijednosti likova, što je u slučaju protagonista tj. glavnih nositelja dramskog zbivanja jedna od najvažnijih vrijednosti u procesu „preglednosti" svega što dramaturško-kompozicijski sastav djela sadrži. Nije stoga neobično prihvatiti izazov antologijskih djela iz književno-umjetničke baštine, "pretočenih", zakonomjernošću umjetnosti plesa, u kategoriju „priče bez riječi”, sa potpunom $i$ analognom skalom vrijednosti likova, njihovih odnosa u dramaturškim čvorištima, uzbuđenja zapleta, usijanja kulminacije i tijeka zbivanja do raspleta, na čijem se kraju „čita" svrhovitost kreacije s idejom poruke i pouke kao poticajem za bogatija i vrjednija razmišljanja svakoga kome je takav tip komunikacije, posredstvom umjetnosti pokreta, ponuđen.

Proučavanje „kreta” kao baze, koja u različitim ritmovima, stvara vrste i oblike kretanja iz kojih se razvija plesna umjetnost, seže u najranije čovjeku poznato vrijeme, obilježeno ritualima religijskih obreda, kao prve „kolektivne koreografije". Kao što svaka misao, čuvstvo i ini pokreti duha imaju svoj poseban ton, imaju i svoj kret. Sjedište kretnje nije $\mathrm{u}$ ovom ili onom dijelu tijela, već se "duša rasprostire" tijelom i svaka njena struja je čitliiva u cijelom živčanom i mišićnom sustavu tijela. Ideju iskazujemo i razmjerno globalnim kretanjem tijela, glave, očiju, ušiju, usta, vrata, nogu, ruku...
Kretnja je vještina koja poučava i upućuje spoznajama o tome kako možemo svoje misli čuvstva i ine duhovne struje i stanja svijesti iskazati zorno, prirodno i lijepo. Dojmovi što ih polučuju kretnje, poznati su kao važan faktor upliva na stavove i odnose, još u doba antičke Grčke i staroga Rima, gdje nalazimo temelje iz kojih su nastale teorije "govora tijelom". Plejada teoretika "govora tijelom", kretnje dijele na više načina. Neki među njima, dijele kretnje na: pokazujuću - kada rukom ukazujemo na nazočnu osobu ili predmet, ili se čini nazočnom, izrazujuću - kada se izborom vrste kretnje priopćava misao ili čuvstvo, slikajuću - kada zamjetljive i osjetilno-pojmljive sadržaje, kretnjama opisujemo, prirodne - kada spontano, u običnom dnevnom iskustvu, iskazujemo temeljna čuvstva iz podloge raspoloženja ili stanja: radost, žalost, strah, srdžba. Hotimične kretnje su one koje nastaju voljnim izborom izričajne mogućnosti tijelom, dok su nehotične bezvoljne, kao što je efekt rumeni na licu uslijed vrste uzbuđenja, ili pak bljedila, kao izraz negativnog naboja duha. Kretnje moraju biti istinite, prirodne, jasne, živahne, krepke i dostojanstvene.

Istinita kretnja predmnijeva oblik kojim se misao potkrepljuje izrazom očiju, čela, obrva, usta. Tako se, primjerice, mir, krotko veselje, očitavaju glatkim licem, otvorenim očima jasnoga pogleda; nemir se čita brzim micanjem usta, boranjem čela, nestalnim, plamenim pogledom. Tako je čitliivo svako čuvstvo, izrazom očiju, čela, obrva, usta, bilo ono jednostavno ili pak složeno i slojevito.

Istinita kretnja predmnijeva sklad izraza svih organa glave s adekvatnom pratnjom kretanja ruku. Istinita kretnja, nadalje, mora imati ekvivalent $\mathrm{u}$ hodu, stavu, držanju tijela, kojima se daje afirmacija vrsti i kakvoći misli i čuvstava. Po hodu, stavu i držanju tijela, je Enej prepoznao božicu Ljubavi. Miran, slobodan i neusiljen hod, stav i držanje, iskazuju miran, tih, stabilan, „fon" raspoloženja, dok se vrste afekata iskazuju žestokim, brzim hodom, kretnjama i izrazom tijela. Tromost pokreta iskazuje pokunjenost, težnja tijela $\mathrm{k}$ predmetu pokazuje požudu ili pohlepu, dok odreknuće tijela pokazuje ogavlje i protivljenje. U scenskom iskustvu se glumac, ovisno o značenju lika u fabuli djela, mora drugačije kretati kao junak, protagonist zbivanja, od „običnog" sudionika u zbivanju. Junak se kreće drugačije, izražajnije od obična čovjeka. Sklad i dosljednost stanja mora biti u svim izabranim vrstama kretanja organa tijela, pa ne 
smije biti prigode u kojoj će „noge biti trijezne dok je glava pijana".

Prirodne kretnje potječu iz jezgrovnoga dijela ideje-vodilje, kojom se osoba zaokuplja u mjeri kojom je želi nedvojbeno, posvemašnje i pravodobno afirmirati i učinili djelotvornom $\mathrm{u}$ iskustvima drugih kojima se obraća.

Razgovjetna, jasna kretnja pridonosi da se redoslijed ideja i čuvstava lako očitava u slijedu i vrijednosti nastajanja i prenošenja drugima, oko sebe.

Živahna i krepka kretnja prati poletnu misao, a ako je misao živahna, „zapaljiva”, a kretnja spora i troma, oduzet će značenje misli i stvoriti „prostor" nesporazumima. Živahnost misli ne znači potrebu silovite (osione) kretnje, pak je sklad smisla ideje-pokretača radnje i odgovarajuće kretnje, jedno od najvažnijih pitanja u svakodnevnom iskustvu, a posebno $\mathrm{u}$ funkciji scenskog oblikovanja situacija i zbivanja.

Dostojanstvenost kretnje mora zrcaliti karakterne značajke lika, pak je ta dimenzija značenja i vrijednosti kretnje posebno važna.

Kretnje mogu „razvrstati” i značajke živothe dobi osobe, spolne značajke i staleške posebnosti, zdravstveno stanje, pa čak i nacionalna obilježja.

U dječjoj dobi su kretnje snažnije, ali oblicima skromnije. Kretnje muškaraca su krepkije, oštrije, a žena slabije, mekanije. Kretnje muškaraca niču iz njihove volje, kreposti, odlučna duha i karaktera, gospodstva, dočim se kretnje žena temelje na njihovoj umilnosti, šarmu, dražesti...

Stalež se očitava osobnim navikama engramiranim u mozgu, koji oličava značajke dnevno-uvježbanog iskustva, pa se lako očitavaju razlike držanja svećenika, odvjetnika, sudaca, učitelja, liječnika, vojnika, mornara, težaka i slično.

I vrste temperamenata, odaju kretnje. Vesele, živahne, kratkotrajne, s obilatim i "oblim” oblicima, kretnje odaju sangvinika. Žestoke, oštrije, trajne i promjenjivog oblika kretnje, označavaju kolerika. Mirnije kretnje, naglašene trajnosti, obilatih čuvstava i umjerenoga ritma, su kretnje melankolika. Skromne, mirne, "stegnute", trome kretnje, otkrivaju flegmatika.

Rasponi kondicije i raspoloženja, također imaju svoj odraz u vrstama i kakvoći kretnji. Slabija muskulatura ima mlitavije i teže kretnje, od bodrosti tijela i duha.

Baš kao i u pojedinačnih osoba, što je duh plemenitiji, izgrađeniji, kretnje su „oblije”, ugodni- je, blaže i dostojanstvenije, tako je i sa narodima. U europskom iskustvu su sjeverni narodi mirniji, umjerenijih kretnji i eliptičnoga izraza duhovnih sadržaja. Dok su južnoeuropski narodi življih kretnji: Talijani, Francuzi, Španjolci, Grci, Mađari, Rumunji, Bugari, narodi slavenskoga juga, Hrvati; sjeverni su narodi suzdržaniji, sažetijih izraza $u$ kretnjama: Rusi, Česi, Poljaci, Nijemci, Englezi, Irci, Danci, Švedi, Norvežani.

Premda nam je kretnja prirođena, ona je nepotpuna u iskazu svega što nam iskustvo donosi i što bi se trebalo i moglo kretnjama izražavati. Stoga je potrebno razvijati i unapređivati izraze kretanja i kretnji, za pun opseg iskustvenoga iskaza tom specifičnom komunikacijskom kategorijom. Motrenje ljudi i njihovih individualnih značajki će zacijelo obogatiti detalje u formiranju kretnji i kretnje "uvoditi” u moguće sisteme, sustava kretanja u cjelini. Dobri uzori za spektar elemenata i njihove slogove $u$ formiranju kretanja i kretnji, kao izraza stanja duha, su zacijelo iskustva dobrih glumaca koji su svoje vještine, uznijete do epiteta umjetnosti, razvili ponajprije pažljivim motrenjem ljudi u svakodnevici, u svijetu oko sebe.

Sredstva formiranja kretnje su: tijelo, glava, vrat, ramena, obličje (obraz), oči, obrve, nos, usta, ruke, prsti, koljena, noge i hod. Primjereno skladu misli i čuvstava, sva sredstva kretnje moraju biti u suglasju da bi, cjelovitošću izraza, mogla ostvariti vrijednu komunikaciju i prenijeti sadržaje čovjeka - čovjeku.

Kada izražava čuvstvo požude, tijelo, glava, ruke, teže naprijed, kao kod veselja, radosti, ljubavi, dobrohotnosti, želje, pouzdanja, ufanja, prijateljstva itd. Čim je veći intenzitet čuvstva, tijelo više teži naprijed, glava, vrat, ruke..., kao kod žestoke ljubavi, čeznuća, smagnuća, veleštovanja itd. Uzmak, stupanje natrag, se očituje kod začuđenja, straha, prepasti, zlovolje, dvojbe...

Čuvstva ugode razvrstavamo u slijedeća: veselje, radost, radovanje, ushićenje, oduševljenje, raskoš, ljubav, štovanje, veleštovanje, strahopočitanje, nada (ufanje), čednost, smjernost, sažaljenje, prkos, hrabrost (srčanost), odvažnost (smjelost), oholost (ponositost), uznositost (bahatost), čuđenje, začuđenje, udivljenje, pobožnost, molba, prosba, znaličnost (Ijubopitnost).

Neugodna čuvstva su: srditost, mržnja, preziranje, gnus (gad), ogavnost, stid, žalost, patnja (bol), jad (tuga), očajnost (zdvojnost), stran, prepast, strava, tjeskoba, ukočenost (zapanjenost), 
bijes, žudnja, pohlepa, čeznuće, zavist, nepouzdanje (sumnjičavost).

Svaka od navedenih vrsta čuvstava ima svoj, gotovo autohtoni sistem kretnji.

Jednostavna čuvstva imaju i čišći, jasniji izraz u mimici i gesti, ali one vrste čuvstava koje su složenijega karaktera, su i složenijega izraza mimikom i gestom.

Veselje, ljubav, štovanje, su jednostavnija "čišća" čuvstva, dok su složene situacije one u kojima se kombinira izvjesno ugodno sa pratećim "težim", neugodnijim čuvstvom; nada i veselje ili strah, prepast sa hrabrosti, oholost sa ljubavi, hrabrost sa tjeskobom. To su situacije i stanja dviju čuvstvenih struja u kojima treba naći mjeru punog izraza svakog posebno i njihova "spleta”, u omjeru u kojem ovaj određuje trenutak doživljaja lika, što je važno, pače i presudno, za radnju i fabulu u cjelini.

U svom najširem smislu, značenje plesa niče iz iskustva njegova ishodišta koja ukazuju da je iniciran, stvaran, onim općim ritmom koji obilježava sve fizičke i duhovne manifestacije čovjekova života. Ples, kao izraz najranijih religija, kao i iskaza ljubavi te temeljne pokretačke sile u supstratu čovjekova bića, je čitljiv kao osebujan sustav u najranijim oblicima čovjekove organiziranosti. Osim toga, tradicija plesa je vezana uza sve čovjekove tradicije, rada i rata, zadovoljstva i odgoja. Plejada filozofa iz najranijih civilizacija, je držala ples "modelom” na kojem treba biti satkan moralni red i život čovjekov, u društvenim odnosima koje kreira.

Kod naroda najranijih poznatih oblika društvene organiziranosti, religija je bila temelj odnosa i smisla, pa je i ritualni ples bio vrijednost najveće religijske važnosti. Plesati je značilo, tada, obožavati i moliti se.

Sve religije, od najranijih do kasnijih koje svoju tradiciju i upliv protežu do dana naše suvremenosti, bile su u svojim počecima plesajuće, pa su se tek kasnije razvijale drugim izričajnim kategorijama. U prvim stoljećima kršćanstva, Herbejci su imali žrtvenik sa plesnim ritualom sličnim mnogima u znatno starijim vrstama obrednih plesova ranijih, različitih civilizacija.

Ovi religiozni plesovi su nekad ekstatični, a ponekad pantomimski. I prirodno je da je tako. Svaki nas put može dovesti do prodora $\mathrm{u}$ „božanske misterije svijeta”.

Autointoksikacija koja se izvodi delirantnim kretnjama, daje pobožnjaku, za časak dokinuće osobne savjesti, što mističnost neprestance predmnijeva. Nasuprot tome, pantomimske igre, u nastojanju da do paroksizma dovedu prirodni izraz i da podražavaju postupke prirode, stavljaju plesača $u$ "božansku sferu” stvaranja i osposobljavaju ga da sudjeluje $\mathrm{u}$ „energiji bogova".

Ples, time, postaje prikazivanjem jedne „božanske drame”, u kojoj vjernik biva pozvan „igrati” jednu ulogu. Tako se rađa obred.

U ovoj sferi pantomimskih plesova kristaliziranih u obred, slijedimo do danas opstojnost plesa $u$ religiji.

Vjerski obredi američkih Indijanaca, kaže Lewis Morgan, uzeli su oblik „plesa sa figurama”, od kojih svaka ima svoje posebno ime, svoju pjesmu, svoju igru i svoje kostime. U toj "točci” su Kršćani prvih stoljeća, koji su obožavali Božansko Tijelo, bili kadri ući u duhovnu svezu sa starim Egipćanima ili američkim Indijancima.

Oni su bili dostojni surađivati, svaki na svoj osebujan način, i sudjelovati u slavljenju jedne božanske mise.

„ISUSOVA HIMNA”, za koju se misli da je najstariji kršćanski obred, poznat nam do danas, koji potječe iz II. stoljeća, nije drugo doli sveti ples.

Stanoviti broj autora smatra da je kršćanska crkva u svojim počecima bila teatar, jer je Kor formirao uzdignutu scenu. Pojam kora je označavao zatvoren prostor za obredno plesanje. Izvjesno je da su za vrijeme pričesti vjernici gestikulirali rukama, ritmizirali nogama i balansirali tijelom.

Kako je glavna funkcija u kršćanskom kultu jedna sveta drama, jedna božanska pantomima, odnosi između kršćanstva i plesa nisu nikada ograničeni na obred mise i njene dalje transformacije još su više ublažene. Sama ideja plesa imala je za prve kršćane sveto i mistično značenje, za njih koji su duboko promišljali o smislu teksta: „Mi smo pjevali za vas, a vi niste plesali", Origen je molio od Boga, nadasve, da bi se u nama mogla ostvariti misterija „,zvijezda koje plešu na Nebu za spas Svemira". Sv. Basil koji se zanimao prirodom, „opisivao" je anđele na Nebu. Kasnije, autor Dieta Sakatiš (vjerojatno Sv. Bonaventura), utjecao je na Dantea koji u Raju „Božanstvene komedije”, ostavlja prilično mjesta plesanju, kao "zanimanju” stanovnika Neba, koji plešu pod Kristovim „ravnanjem”. 
Pravi ples, ne samo ukočena forma koju možemo slijediti od najranijih misa, često je bio uvođen u kult kršćana, prvih stoljeća njihova razvitka. On je bio uobičajen sve do novijih vremena, posebice $\mathrm{u}$ nekim skrovitijim područjima kršćanske religije, u pojedinim dijelovima svijeta, gdje se održao i do danas. Ples se održao u engleskim katedralama sve do XIV. stoljeća. U Parizu su svećenici plesali za Uskrs, u koru, i to do XVII. stoljeća.

Roussillon je pokrajina sa španjolskom tradicijom, $\mathrm{u}$ kojoj je ples imao najdublji korijen i cvao najduže. U katedralama Seville, Toleda, Valensie, bilo je plesova koji se, kao u Sevilli, održavaju do danas u posebnim svečanim zgodama. $U$ Alaro dela Mallorca postoji jedna plesna grupa El Cosiers, koja na dan Sv. Roka, patrona toga kraja, odjevena $\mathrm{u}$ slikovite kostime, sa tamburinima $\mathrm{u}$ rukama, pleše do glavnog oltara, da bi i nakon obreda, plešući izišla iz crkve.

Uopćeno govoreći, prepoznatljivo je da je ples jedan od najbitnijih sastojaka svake žive i nedegenerirane religije. Stoga je i svaka nova religija, u povijesnom razvitku čovječanstva, religija društva, a ne „beskrvna” religija razuma, vezana za plesni izraz.

Osim što je sastavni dio čovjekova vjerovanja u bogove kao više sile, ples je izrazio čovjekove emocionalne temelje ljubavi. Analognost te vrste plesa nalazimo u ritmiziranim kretnjama drugih vrsta živih bića, od insekata do sve složenijih.

Može se reći da ritmizirano kretanje kod insekata i ptica, često čini bitan dio „udvaranja”. Ovaj paraples insekata i ptica, pojavljuje se i kod najprimitivnijih plemena $\mathrm{u}$ različitim dijelovima svijeta, od pradoba civilizacije, poglavito u Africi. U jednom simboličkom i konvencionalnom obliku, taj ples ljubavi se pleše i u suvremenosti. Od prvih dana kršćanstva do naših dana, ova vrsta plesa je pobuđivala prigovore sa stanovištva ćudoređa, a prema jednom autoru iz VIII. stoljeća, je taj ples samo serija "nepoćudnih i razvratnih pokreta koji bude tjelesnu požudu".

Ali u prirodi, kao i kod primitivnih starih plemena, ples upravo tu crpi svoju najveću vrijednost. On je vrsta sredstva za udvaranje, štoviše, on je vrsta ljubavnog novicijata, za koji se može tvrditi da je divna ljubavna priprava. Kod nekih kultura, kao kod Omahasa, ista riječ označava i pojam ljubavi i pojam plesa. To nas dovodi do područja seksualne selekcije: mužjak mora pridobiti ženku svojom ljepotom, svojom energijom i spretnošću, on to čini imprimirajući snažno "svoju sliku” u maštu one koju osvaja, da se napokon u njoj rodi želja da pobijedi svoju suzdržanost i da se poda. U tome je pretežito uloga mužjaka u iskustvima živih bića. Leptiri, faleni, afrički nojevi i fazani Sumatre, kao i mnogi njihovi supripadnici, namećući se odabranoj ženki najsjajnijim zalozima budućeg naraštaja vrste, bili su preteče čovjeka u čudesnom erotičnom "ritualnom kretanju”. S naznačenog stajališta je očevidno da ples vrši dvostruku funkciju. $S$ jedne strane, tendencija plesanja, budeći se pod tamnim pritiskom erotičnog nagona, proizvodila je najbolje moguće za što se individum osjeća sposobnim stvoriti, a s druge strane, $\mathrm{u}$ trenucima ljubavnog udvaranja, razvijanjem aktivnosti time potaknute, nastaju osjećaji osebujne mogućnosti ljepote, koji nastaju napokon kod čovjeka, svjesnim činom.

Kod čovjeka je taj erotski naboj u plesu jednako izražen. Muškarci nisu jedini koji polučuju ljubav žena. Po jednoj modifikaciji, u metodi seksualne selekcije, događa se često da muškarci ne plešu u ime osvajanja žena, nego i žena pleše u osvajanju muškarca trudeći se, svako sa svoje strane, da u jednom izrazu kurtoazije, izazove i privuče pozornost partnera. U mnogim krajevima svijeta "sezona ljubavi” je vrijeme kada svaki spol, došavši do spolne zrelosti, nastoji „plesati” u prisutnosti drugoga spola. Tu se, sad jedan sad drugi, ili pak oba zajedno, uz frenetični napor, nastoje razviti u snagu, energiju, spretnost i izdržljivost, ljepotu i dražest, koji ih nagone da se bace u „vitalni vrtlog sočnog života".

S aspekta seksualne selekcije, može se jasnije razumjeti ogromni žar koji svaka strana čudesnog „„čovječanskog organizma" unosi u ples.

Ljudi i žene svih rasa i kultura, učinili su čuda od spretnosti i strpljivosti u pribavljanju ritma i glazbe na najnevjerojatnijim i „najbuntovnijim" dijelovima tijela.

Svi su izgarali od želje da se izraze u što jačim i sjajnijim slikama. Snažnim narodima sjeverne Europe, ples se prirodno predstavlja tako da se mora izvoditi nogama. To je toliko prirodno da engleski pjesnik Swinburne pretpostavlja sasvim razumljivim da je ples Salome bio „treperenje no$\mathrm{gu}^{\prime \prime}$. Međutim, u nekoj ranijoj epohi, shvatio bi se ples Salome sa više slobode $i$ više preciznosti $u$ ukupnosti izraza tijelom. Kao što je Enlart ustanovio na jednom zaglavlju samostana Moisac, iz XII. stoljeća, Saloma pleše držeći u uzdignutoj ruci 
castagnete. Na jednom od zapadnih portala katedrale $\mathrm{u}$ Rhouenu, koji datira iz početka XVI. stoljeća, Saloma pleše rukama, dok u Hemelvedeghemu ona izvodi „maurescu”, vrstu trbušnog plesa.

Na suprotnoj strani svijeta, u Japanu, a napose na Javi i Madagaskaru, ples se isključivo pleše rukama. Na mnogim otocima Pacifika, još se rukama pleše, ili čak samo prstima. Plesati se može i u sjedećem stavu, kao na otoku Fiđi, za vrijeme pripravljanja svetoga pića ava. U nekim predjelima južnog Tunisa, održava se ples kose. Djevojke, udavače, provedu cijelu noć, (ako ne padnu izmorene), njišući glavu u ritmu pjesme, održavajući kosu u jednom stalnom treperenju. $\mathrm{U}$ nekim krajevima Afrike i djelomice u Polineziji, ples je posve sličan plesu staroga Rima; izvodi se vibratornim ili relativnim pokretima grudi ili bedara. Ples ove vrste ipak nije potpun, sve dok igra glavnih mišićnih skupina nije skladno izmiješana. Čim dva spola sudjeluju u sličnoj vježbi, razvijenoj $\mathrm{u}$ jednu ljubavnu pantomimu, idealiziranu, nastaje već posve jasan erotični ples. Ove vrste plesa su ponekad u Španjolskoj dobile svoj najplemenitiji i najskladniji izraz. Dražest koju oni stvaraju dolazi iz odnosa iskonske primitivne mističnosti i seksualne selekcije. Izgleda, prema pripovijedanju očevidaca, da su ti plesovi, posebno u XVIII. stoljeću, došli u Španjolskoj do velike popularnosti. Kako nam svjedoči Baretti (1770. godine), aragonski kanonik, crkva je usprkos očevidne nečednosti ovih plesova, šutke njih podržavala kao izvrstan odušak sigurnosti protiv emocija. Ti plesovi su očarali narod, strane posjetitelje Španjolske. Ozbiljni putnik Pyron, koncem XIX. stoljeća, govorio je o strasnim i nježnim pokretima plesa, o očaravajućim položajima i „ljupkoj krivulji ruke”. Kad gledate lijepu Španjolku kako pleše, kaže on, dolazite u kušnju da "vragu date svoju filozofiju”. Čak i veleuvaženi svećenik kakav je bio Joseph Towenseld, priznaje da je uvidio kada bi ples, fandango, bio odjednom uveden $\mathrm{u}$ crkvu, najozbiljniji među vjernicima bi ustali da se pridruže ovoj "razvratnoj pantomimi”. Ovdje se dodiruje hrid, na kojoj se, kada je civilizacija napredovala, razvio i potonuo primitivni ples seksualne selekcije. I ova predrasuda civilizacije otišla je tako daleko da su napadnuti i sami primitivni plesovi iako afričke Pigmeje, opisuje Sir Johnstone, kao narod miran i vrlo visokog morala.

No, što se tiče njihova plesa, to je posve drugačije. Iako ih Johnstone, zaslijepljen europskom civilizacijom, drži grubo nepristojnim, on pošteno dodaje i ne opažajući tu protuslovlje, da se oni plešu sasvim poklonstveno. Izgleda, naoko, da od plesa u ljubavi i njegove svete uloge u religiji, do plesa koji se smatra umjetnošću, profesijom ili zabavom, postoji jedan "skok" vitalne funkcije. Zapravo je prijelaz postupan i započeo je davno na raznim točkama svijeta. Svi elementi koji tvore "ljubavno udvaranje", teže doći pod skiptar umjetnosti. Njihova estetička zabavnost, samo je odjek prvorodne vitalne radosti. Ples je morao prvi otkazati ovu težnju. Isto je i s religioznim plesom. Plesanje je također postalo profesijom, (kao i svećeničko zanimanje). Kao i svećenici, i plesači su formirali svoju kastu. To se, primjerice, vidjelo na starom Hawai-hula, gdje jedan religiozni ples zahtjeva posebnu naobrazbu i teško, naporno vježbanje, štoviše on je tvorio i posebne propise u vršenju svetih obreda. Stoga su taj ples plesali plaćeni ljudi koji su pripadali profesionalnoj kasti. U Indiji, svete djevojke, plesačice, devadesisi, su istodobno i religiozne plesačice. Udate za bogove, njih plesu uče Brahmani, one sudjeluju u religioznim svetkovinama., a njihovi plesovi predstavljaju život Boga, "njihova supruga", i osjećaj ljubavi koju njeguju prema njemu. One daju i predstave kod bogataša koji ih plaćaju. To se njeguje u tolikoj mjeri da stranac teško može raspoznati devadesise od rameđenisa, uličnih plesačica, čije je porijeklo posve drugačije i koje pokazuju samo igru ljudske strasti. Portugalski zavojevači Indije, su ih nerazumno nazvali balheiders, što smo mi preveli kao „bajadere".

\section{KLASIFIKACIJA PLESA}

$\mathrm{U}$ našem modernom vremenu, profesionalni ples shvaćen kao umjetnost, odvojio se od religije i, u svom vitalnom smislu, od ljubavi. Gotovo je nemoguće promatrati ga samo $u$ zapadnoj civilizaciji, izvoditi tradiciju iz jednog ili drugog izvora. Ako promatramo razvitak umjetnosti plesa u Europi, možemo, čini se, raspoznati u njegovoj tradiciji, dvije struje, koje su se ponekad miješale, ali koje su ipak ostale bitno različite u svom idealu i u svojim nakanama. Mogli bismo nazvati Klasičnom, stariju tradiciju za koju se može smatrali da potječe iz Egipta, a Romantičnom, tradiciju talijanskog podrijetla, koju posebno poznajemo iz baleta. U svom čistom obliku prva je struja plessolo, osnovan na ritmičkoj ljepoti i snazi izraza ljudske ličnosti, kad je njezina energija skoncentrirana u strasnim kretnjama. Dok je ples skoncentriran, mimički i slikovit, u njemu je individua po- 
dređena širokom i raznolikom ritmu grupe. Mogla bi se lako zamisliti i jedna druga klasifikacija, ali ova je dovoljno jednostavna i instruktivna za ovaj prigodni pristup. Egipat je, tomu se teško može sporiti, bio tisućama godina, jedan veliki centar odakle ples širi svoj upliv, možda i najveći kojega je svijet vidio.

Možemo se složiti sa historicima, koji stari Egipat nazivaju zemljom-majkom svakog civiliziranog plesa. Stari slikari zidina na obali Nila, nisu jedini koji svjedoče o spretnosti Egipćana. Zar nije zanimljivo da su najveći dio glazbala koja su i danas u uporabi, kao pridružena plesu, po porijeklu ili usavršenju iz Egipta. Gitara-egipatska i njezino ime, je služilo kao hieroglifski znak kada su zidane piramide. Simbol-tamburin, castagneti, u jednom ili drugom obliku, bili su poznati starim Egipćanima. I sa plesom, ovi su se instrumenti morali razviti još $u$ vrlo davnim vremenima. Svugdje oko obala Sredozemnog mora, ovog velikog ognjišta naše civilizacije, pa i izvan toga područja, u Cadisu, nalazimo jedan etablishman za ples sa bitno egipatskim karakterom, koji je postao bazom španjolski škole. Nil i Cadis, bili su dva velika centra plesa. U antičkom svijetu, Martial nam spominje oba ova centra jer je svaki snabdijevao Rim plesačicama. Ovi plesovi, egipatski kao i galitanski, bili su individualni izraz plesača i njegove umjetnosti. Odjelo je često, a ponekad i posve odbačeno, u njima imalo vrlo ograničenu ulogu. Oni su bili i još uvijek su jednostavni, osobni i zanosni, dakle klasični u onom smislu u kojemu je, u književnosti klasična Katulova poezija. Nije bez značenja da je Egipat, nakon pedeset stoljeća, sačuvao gotovo nepromijenjene svoje tradicije, svoju tehniku, i svoju okretnost u plesu. Isto kao nekada, odijelo je jedan element gotovo sporedan $\mathrm{u}$ ovoj umjetnosti. Sorel primjećuje da je jedna očaravajuća plesačica 18. dinastije, čije je crte reproducirao, pod providnim velom, vjerna slika jedne suvremene alah koju je vidio na plesu $u$ Thebi: ista figura, čak isto češljanje i nakit. Jedan egipatski liječnik, ginekolog je pričao da plesačica, ležeći na leđima, sa časom punom vode postavljenom na jednom kraju trbuha, može kontrakcijom mišića preliti vodu iz pune čaše u praznu. Nema sumnje da to i nije striktno ples nego neka vrsta tehnike, koja čini temelje klasičnog plesa. To pokazuje sa koliko se preciznosti još i danas proučava tehnička strana egipatskog plesa.

U knjizi koju je Emmanuel posvetio plesu, vidimo na grčkim vazama, istu igru ruku, isti način njihanja, isti način previjanja tijela, kao i onaj koji je naslikan na egipatskim spomenicima. Više kretnji za koje se mislilo da su „moderne” bile su već popularne u Egiptu i Grčkoj, antičkoga doba. Udaranje rukom o ruku, da se održava tempo, nalazi se još $\mathrm{i}$ danas $\mathrm{u}$ španjolskim plesovima. Ipak, jasno je da se grčki ples na ovoj općoj klasičnoj i sredozemnoj osnovi razvio u tako profinjenu i tako posebnu vrstu, da nikada nije izvan Grčke vršio nikakva upliva. Međutim, ples je u Grčkoj, postao najkarakterističnija i najviše njegovana umjetnost. Moglo bi biti da se grčka antička drama razvila iz plesa i da joj je ples uvijek sačinjavao jedan bitni plastički element. Eshilu se pripisuje razvoj tehnike plesa, a Sofoklo je plesao u svojim vlastitim tragedijama. Bez ikakve sumnje, grčki ples je težio da pređe osnovne granice klasičnoga plesa i na taj način prethodio baletu. Međutim, pravo se "vrelo plesa" nalazi u starom Rimu, gdje se razvila pantomima, svojom koncentriranom i pitoresknom metodom ekspresivne akcije.

Italija je kolijevka romantičnog plesa. Isti poriv koji je doveo do pantomime, urodio je gotovo tisuću godina kasnije i $\mathrm{u}$ istom talijanskom kraju, modernim baletom.

Može se vjerovati da bi mogli u oba ova slučaja istaknuti utjecaj etrušćanske i toskanske kulture koja se tu tako dugo razvijala.

U toj kulturi je postojao genij ekspresivne dramske i piktoralne umjetnosti, kao što svjedoče zidovi etrušćanskih grobnica, Boticcelijeve slike i njegovih toskanskih kolega. Općenito se misli da moderni balet vuče svoje podrijetlo iz paradnih predstava koje su priređivane za vrijeme svadbe Galezza Visconti, milanskog vojvode, 1489. godine. Ovakve predstave su ušle u modu i na ostalim talijanskim dvorovima, uključujući tu i Firenzu. Kada je Katarina Medicci, postala kraljicom Francuske, donijela je talijanski balet u Pariz. Ovdje se on brzo razvio, kraljevi i kraljice mu se dive, a veliki ga državnici štite i podržavaju. Odmah potom se balet ustalio, živeći intenzivnim životom i rastući vlastitim, autohtonim snagama, potporom glazbenika, umjetnika i otmjenih plesača. Mnogo više no antički ples, koji ovisi tako jako od jednostavnih osobnih svojstava, romantični ples je oživljen prenošenjem i upijanjem novih upliva. Potrebno je međutim bilo da se u ovom novom zamahu razvitka sačuva bitna osnova tehnike i tradicije.

U XVII. stoljeću, Lully je uveo žene u balet, Lecamargo odbaci teške kostime, već tada u modi, 
omogućavajući svu slobodu i dražest plesa koji se izvodi. Noverre, usavrši sceneriju, koja je razvijena jedino pokretom i plesom i tako stvori od baleta potpuni oblik umjetnosti. Francuski balet XVII. stoljeća došao je tako do visokog stupnja savršenosti, dok je u svojoj domovini Italiji počeo slabiti. Milano, u kojem je balet nastao, postao je utočištem jedne određene tehnike koja je dovodila do vrhunske profinjenosti.

Utjecaj francuske škole se održao do XIX. stoljeća kao živa sila, šireći se po svijetu zahvaljujući određenim plesačima. Kada su ovi iščezli, balet je lagano ali sigurno slabio. I ukoliko je opadao kao umjetnost, njegov kredibilitet i popularnost su opadali u istoj mjeri, i to tako da više nikako nije bilo „pristojno uživati u plesu”. Prije kojih stotinu godina, nekoliko ličnosti koje su zagovarale ovu umjetnost, iako su bile malobrojne, imale su muke da ga promaknu u sredinama koje su već zazirale od njega. U knjizi iz 1906. godine, izjavljuje jedan povjesničar plesa "da je balet stvar koja pripada prošlosti”, i koja se, s obzirom na moderne ideje, neće vjerojatno više nikada pokazati. Ovaj povjesničar nije spominjao ruski balet, ali tek što je knjiga objavljena, pojavio se ruski balet da zaniječe njegovo preuranjeno proročanstvo, podižući ples na tako visoki stupanj savršenosti, koji je on rijetko prerastao, davši mu oblik ekspresivne emocionalne, pa i strastvene umjetnosti.

\section{RUSKI BALET}

Ruski balet je izdanak francuskog baleta i njegov „slučaj” pokazuje koliko oživljavajući upliv u romantičnom plesu vrši „transplantacija”. Carica Ana ga je uvela u Rusiju, 1735. godine i za ravnatelja angažirala učitelja francuskog baleta i jednog napuljskog glazbenika. Tijekom narednog stoljeća, ples je u svojim tradicionalnim granicama došao do velike tehničke savršenosti. Glavni su plesači dolazili iz Italije.

Tek krajem XIX. stoljeća je ova čvrsta disciplina i njene stare tradicije, oživotvorena utjecajem zemlje u kojoj je polako bila uhvatila korijen, dala umjetničku realizaciju jedne izvrsne i žive ljepote. Ovo sjedinjenje, kada je napokon obavljeno, podiglo je „vrstu revolucije” dok je sam balet primljen kao neka izvrsna novost. Međutim, tradicija baleta je bila u Rusiji „egzotična importacija”, bez stvarnog života i nije imala svijetu što dati, dok je pak ruski balet, lišen tradicija, ako možemo shvatiti istu stvar, bio bezobličan ekstravagantan, bizaran i lišen svake više estetske svrhe. Ono što mi vidimo u ruskom baletu, onakvom kakvim ga postupno poznajemo, to je sjajna i snažna tehnička tradicija koju je konačno kombinirani genij slikara, skladatelja i plesača, doveo do potpune sraslosti sa sredinom od koje balet bijaše udaljen više od jednoga stoljeća. Napokon je tradicija "upila” ruski muzikalni duh, osjećaj ritma i rusku spretnost vladanja, sa sjajnim bojama i možda, ponad svega, orgijaški temperament i običnu strast Slavena za popularne plesove, koja se pokazuje u svim ograncima rase: kod Poljaka, Čeha, Bugara... Na taj način, zahvaljujući spomenutom sjedinjenju, naša epoha je svjedokom najsjajnijim trenucima u cijeloj povijesti romantičnoga plesa. Kako god gledali, ples ne može iščeznuti. On će uvijek imati svoje renesanse, ne samo kao umjetnost nego i kao društveni običaj, ples neprestance izvire iz narodne duše. Nema ni puno stoljeće otkako je tako nastala polka, koju je improvizirala jedna češka sluškinja, Ana Slezakowa, za radost svome srcu. Zahvaljujući jednom artisti, koji je, slučajno je vidjevši, zabilježi, polka postade stalan oblik sposoban za veliku popularnost koja ju je čekala. Ples oduvijek postoji kao spontani običaj, kao socijalna disciplina. Tako nam se on pokazuje ne samo kao umjetnost, nego i kao moral, kojeg nagoni jedan te isti poriv. I tako je izvršena društvena unifikacija. Osim rada, ples je u običnom životu, glavni činitelj koji pridonosi socijalnoj solidarnosti. Ustvari, on je najbolja priprava za sve kooperativne akte u životu. Sva naša odmakla civilizacija, a grosse, ustrajno tvrdi, osnovana je na plesu. Ples je učinio čovjeka druževnim; socijalizirao ga je brže i lakše.

\section{PLES KAO „ZNANSTVENA METODA”}

Tako je dakle ples, promatran u svom najširem smislu, imao posebnu vrijednost kao "nacionalna znanstvena metoda”. Ukoliko je civilizacija postajala svjesnijom sebe, to se i ostvarilo. Jedna stara kineska poslovica kaže: $\mathrm{O}$ jednom kralju se može suditi po stanju plesa, za njegove vladavine. Isto tako, kod starih Grka, kaže se da je ples u samoj osnovi svake vojničke i vjerske organizacije dorskih državica.

Uzet u svom užem smislu, primijenjen na individualni odgoj, svoju važnost je ples već pokazao u jednoj vrlo jednostavnoj epohi ljudskog razvitka, ali se još bolje ostvario u antičkoj civilizaciji. Dobar odgoj, kaže Platon u "Zakonima”, (posljednjem djelu njegove mudrosti), sastoji se $u$ tome da se zna dobro pjevati i plesati. 
I za naših dana XX. stoljeća jedan od najsrdačnijih i najupućenijih odgajatelja, žalio je dekadanciju umjetnosti plesa. Renesansa plesa, prema Stanleyu Hallu, je imperativna potreba da bi uravnotežila nerve, odgojila strasti, učvrstila volju i napokon, u sklad dovela osjećaje i inteligenciju, sa tijelom koje ih nosi.

Međutim, ne bi se nikako moglo utvrditi da su ove funkcije plesa ostvarene i unesene $u$ odgoj. Jer, ako je istina da je ples začedio moral, isto je tako istina da je i moral, po nekoj ironiji sudbine, postavši insolentan, pokušao uništiti svoga tvorca, što mu je za stanovito vrijeme vrlo dobro polazilo za rukom. Ima četiri stoljeća kako je ples napadnut od onoga duha što ga u Engleskoj nazivaju puritanizmom, ali koji je $\mathrm{u}$ toj epohi bio raširen po velikom dijelu Europe; jednako aktivan u Češkoj i u Engleskoj, on je označavan kao „opći juriš rastućeg urbanizma protiv starog ruralizma."

Ovaj duh puritanizma nije lučio dobro od zla, niti je promišljao što bi bilo kada bi ples posve iščezao. Tako je došlo je do toga, kao što je primijetio Remy de Gourmont, da je cabaret "usvojio" ples, a alkohol „zamijenio" violinu. Ali, kad promatramo funkciju plesa, sa jednog višeg obzora, ova epizoda njegove povijesti prestaje zauzimati tako važno mjesto. Jedna "pobjeda" nad plesom nije, konačno, nikada značila trijumf nad plesom, pa čak ni za moral, jer jedna umjetnost nekad tako intimno vezana sa najfinijim i najdubljim izvorima života, afirmirat će se uvijek sve jače, uplivnije.

Ples je najuzvišenija, najosjećajnija i najljepša umjetnost, koja se otkriva ne samo kao slika ili apstrakcija života, nego kao i sam život. To je jedina umjetnost, kako kaže Rachel Varnhagen, čiji smo subjekt sami mi. Treba dodati da je ples, osim njegove mnogostruke praktične važnosti, imao uvijek simbolično značenje. Mark Aurelije, rado je gledao na život ",kao umjetnost sličnu plesačevoj”, iako se ovaj carski stoik nije mogao suzdržati da ne doda, da u izvjesnom pogledu više sliči „umjetnosti borca”. Za naših dana, Nietzsche je bio stalno obuzet "koncepcijom života kao plesom", u kojem plesač stječe ritmičku slobodu i skladnost duše u sjenci istine Damoklovih mačeva. Ples se nalazi u početku umjetnosti, a mi ga slijedimo također i do danas. Prvi tvorci civilizacije su stvorili ples i današnji filozof, ploveći iznad tamnih ponora ludila, krvavih nogu i mišića nategnutih do ekstrema, izgleda u svojim osobnim očima, kao da prede povesmo plesa.
Hoće li se moderni balet razvijati, cvasti ili će se „utopiti” u klasični balet, ovisi najviše od ove spomenute gospode. Od svih umjetničko-plesnih oblika, samo je moderni balet originalna američka tvorba. Već i sam izraz „moderni balet” je u stanovitom smislu pogrešan, jer moderni ples nije više nužno moderni. Njegova povijest započinje s ovim stoljećem. Semantičari su "pomiješali” stvari, pa se osjeća nakana da se "modernom baletu” prida značenje „avangardnog plesa”, a izraz "moderni balet" zadrži za njegove starije oblike.

Bilo bi nedvojbeno uputnije pronaći neki manje prolazan izraz za ples koji nije ni folklor, a niti je klasika. Možda ga nazvati „ekspresivnim plesom" koji manje obvezuje, jer mnogo toga može ponuditi. Ipak ostaje sintagma "moderni balet", koja je toliko uvriježena da je teško mijenjamo. Može se samo između prve riječi i druge, staviti crtica koja ih razdvaja i ukazuje da prvu riječ ne treba shvatiti kao pridjev, nego kao dio složene imenice.

Moderni ples nije nikada započeo u Americi. On je u njoj niknuo. Prvi njegovi sljedbenici nisu stvarali školu, niti razvijali tradiciju, doli vjeru u slobodu, nekonformizam i američki balet. Začetnicom takvog poimanja plesa je bila slavna Isadora Duncan, čiji je upliv početkom stoljeća bio očaravajući.

Pokušaji da se Isadorin ples sa lepršavim velovima uz pratnju klasične glazbe, podražavaju, završili su neuspjehom, bez genija njene osobnosti.

Temelje američkom modernom baletu nije dala legendarna Isadora, već Ruth Saint Denis i Ted Shawn. Ovaj je par utemeljio Danishawn School, u kojoj su se učile sve vrste plesa. Ta je škola dala tri značajna učenika: Martha Graham, Doris Humphrey i Charles Weidman. Njih troje su bili preteče modernoga plesa u suvremenom smislu.

Osnovni stil plesa Marthe Graham i stil Doris Humphrey su posve različiti.

Martha Graham se podređuje „kontrakciji i opuštanju mišića" pri prirodnom disanju i taj ritam primjenjuje na sve pokrete tijela. Skrb za afirmacijom prirodnih pokreta daje njenom plesu vrstu eksplozivne energije koja, ne samo što se može usavršavati do virtuoznosti, nego zahvaljujući kontrastima između naprezanja i opuštanja, kontrastima koji sadrže i bit toga stila, moguće stvoriti veliki raspon emocionalnog potencijala $i$ sugestivnosti izraza u izvođenju. 
Otkriće Doris Humphrey nije manje zanimljivo. Njen se stil temelji na „padovima i dizanjima". Doris Humphrey ima ples kao luk između dvije smrti: „smrti” u posvemašnjoj nepomičnosti na zemlji i "smrti" u balansiranju, kada tijelo pruža apsolutni otpor sili-teže. Doris Humphrey „prodire u unutarnju dramu tijela" koje pada i specifičnih pritisaka i naprezanja tijela koje balansira u mirovanju.

Iza tih dviju "teorija” i estetika, kriju se posve različite nastavne metode $\mathrm{i}$ što je možda najvažnije, vrlo različiti moralni ciljevi. Doris Humphrey ie znatno više socijalno orijentirana posebno u vrijeme tridesetih godina stoljeća, kada je sa svojim suradnikom Weidmanom, zagovarala djela naglašeno socijalnog značenja.

Martha Graham je manje zaokupljena pitanjima neposrednosti života. Ona preferira istraživati „unutarnje predjele duše", služeći se plesom i simbolima da bi razotkrila psihološke „mehanizme” svojih junaka.

Bilo je nastupilo jedno razdoblje rascjepa tj. kada su pristaše modernoga plesa odbijali priznati klasični balet ili, ako su ga uvažavali, nijekali su mu veće umjetničko značenje. To razdoblje rascjepa je izazvalo mnoge rasprave i polemike. Bilo je nastalo burno vrijeme koje je sedimentiralo poimanja svrstana u nekoliko smjerova kretanja plesne umjetnosti. Jose Limon, sljedbenik tradicije Doris Humphrey je jedan od najvećih suvremenih američkih koreografa, čija nam plesna trupa pruža i nadalje Humphreyev plesni stil. To je izvrsna trupa i Limon je veliki koreograf i vrlo utjecajan pedagog. On predaje na Juilliard Music Academy i njegov je upliv daleko najprestižniji. Međutim, širina njegova upliva se ne može usporediti s uplivom Marthe Graham. Ona i njena škola su postale praktičnim sinonimom modernoga plesa. Grupa Marthe Graham se uzvisila do tolikoga stupnja međunarodne slave, da se može uspoređivati sa velikim kazališnim i plesnim ansamblima svijeta. Ta škola je velikog značenja, njoj teže mladi Amerikanci koji se žele afirmirati u području modernoga baleta, a što je još značajnije, mlađi Europljani koji raspolažu dovoljnim sredstvima. Repertoire Marthe Graham i još značajnije, njena tehnika, odnijeli su pobjedu. Teško je precizirati zašto je Martha Graham prevagnula svojim uplivom. Vjerojatno je tu bilo izvjesne sreće; sudbina je htjela da Martha stekne bogate imućne zaštitnike i to joj je uvijek bilo od pomoći. Međutim, čini se da je Martha Graham uspjela, potpunije izraziti sebe.
Ona je bila prva koja je postigla ogroman ugled $\mathrm{u}$ svijetu.

Doris Humphrey je prikazala svoj stil u inozemstvu, ali je on bio slabije dojmljiv. Doris je bila veliki pedagog. Njena knjiga „Umjetnost stvaranja plesa” („The art of making dances") standardni je priručnik iz koreografije, ali su njeni stvaralački impulsi bili manje snažni od onih Marthe Graham. Martha Graham je bila istinski bolji koreograf. Pobjeda Marthe Graham je zamjetljiva u njenom uplivu, a o tome se može najbolje suditi po njenim brojnim učenicima i sljedbenicima.

Svijet je pun učenika i sljedbenika Marthe Graham, iako je nekolicina njih napustila njen studio, kao što su: John Buttler, Robert Cohan, Erick Hawkins, Merce Cunningham, Jean Erdman, Stuart Hodes, Pearl Lang, Donald Mc Kayle, Norman Morrice, Betram Ross, Anna Sokolow, Glen Tetley, Paul Taylor, Yuriko. Trijumf Marthe Graham u svijetu modernoga plesa je značio jednostavno mir. Desetljećima su se predstavnici modernoga plesa međusobno oštro sukobljavali. Tome nije bilo lijeka. Svi su bili Marthina "djeca” i svi su sretno plesali $u$ „predvorju raja”. Plesali su dok nije došlo do rascjepa, isto onako dubokog, kao što je bio rascjep između Marthe Graham i Doris Humphrey. Novi rascjep u svijetu „modernog baleta", doveo je do toga da su se sukobili i Paul Taylor i Merce Cunningham. Ta dvojica i njihove trupe, duboko se razlikuju. Njihovi pogledi na ples isto su toliko različiti koliko i njihove osobnosti, a njihove osobnosti isto koliko i njihove koreografske aspiracije i postignuća. Obojica su započeli kod Marthe Graham, obojica su „zaludjeli sinovi" koji o Marthi govore iskrenom ljubavi ali i dubokim otporom. „Bilo je divno raditi s njom, pa ipak se nisam sklon podvrći njenoj dominaciji", rekao je jednom zgodom Taylor. Obojica se međutim dive Marthi i na svoj način joj ostaju uvijek sljedbenici, Apolona ili Dionisija, osim ako, kao Stravinski, nisu u stanju klanjati se i jednom i drugom Bogu.

Reći da Taylor, kao umjetnik, naginje više Apolonu, a Cunningham Dionisiju, znači možda pokrenuti više pitanja nego što ima odgovora. Međutim, istina je da među njima dvojicom opstoji značajna razlika u metodama. Po općem priznanju, njihove trupe su pored Marthine, najuvježbanije družine „modernog baleta" danas u svijetu. Oni su, u općem smislu riječi, okupili najbolje plesače i rade sa njima neumorno, usavršavajući ih i ispra- 
vljajući, tražeći i dobijajući apsolutnu lojalnost od svojih sljedbenika. Dok Marthina trupa broji 20 plesača, Chunningham i Taylor nemaju više od po deset, svaki. Možda vam se ne bi dopalo to što rade, ali se ne može poreći da sve što rade, rade izvanredno. U koreografskom pogledu, razlika između njih dvojice može se jednostavno rezimirati: iako se obojica služe sličnom temeljnom tehnikom, u oba slučaja je u pitanju osobna adaptacija Marthinu stilu, Tavlor se pridržava „pravih linija”, njegova je koreografija postupna, korak po korak, dok Cunningham nije nimalo "pravocrtan”, njegov se ples raspršuje u mjehurima kao da je scena „minsko polje” po kojemu se pleše. Za Cunninghama nema propisane logike. Događa se ono što je nužno. Kod Taylora, iako se i on često služi nasumce složenim pokretima, postoji uglavnom predvidljiva, gotovo klasična, amplituda razvoja radnje.

Nije slučajno što Cunninghamu najviše "leži” glazba Johna Cagea i Gordona Mumma, dok se Taylor oslanja i na Händela i na Beethovena. Njihova koreografija je individualno jasno razvrstana. Ona ima, kako se to u umjetničkom svijetu kaže, svoj „profil”, ono neizrecivo nešto po čemu se prepoznaje djelo svakog umjetnika.

Taylorova koreografija se oblikuje senzualnijim tijekom. Ona je, osim toga, puna oštre satire, koja se znatno razlikuje od ",antičkog" Cunninghamova humora, kao i izvanrednog imaginativnog čuvstva za one najvažnije aspekte plesa koji se zove „baletna slika”. Baletna slika je korak ili gesta koja dočarava neku misao ili emociju na sasvim neliterarni, vizualan način. Taylor ima jednako tako veliki dar zapažanja u odnosu na ljude, a to je još jedan od elemenata njegove snage, veliki arhitektonski smisao za specifičnu i zadovoljavajuću baletnu konstrukciju. I Chunningham je također veliki majstor svoga posla. Njega mnogo više zanima avangardno $u$ umjetnosti. Međutim, za razliku od većine avangardnih plesača, on sebe ne uzima "suviše ozbiljno" i svoje velike koreografske sposobnosti namjerno stavlja $u$ službu ,jednostavnih ciljeva”. Kod Cunninghama ima neke čari i nepretencioznosti koja uvijek razoružava. Rođen je dvadesetih godina u državi Washington, gdje je učio folklor, tzv. step, i tradicionalne okretne-salonske plesove. Martha Graham ga je 1940. godine pozvala k sebi i on se pridružio njenoj trupi kao plesač, gdje ostaje do 1945. godine. Tih se dana činilo da je moderni ples nepodmitljiv. Ako bi se u tim „čistunskim” krugo- vima klasični balet uopće spomenuo, to se činilo gotovo bojažljivo, kao kada bi puritanci govorili o Antikristu. U to vrijeme je Cunningham odlučio uzeti satove klasičnog baleta. Takva je odluka bila tipična za njega, jer je uvijek bio više nekomformist nego puritanac. Učio je u školi američkog baleta Georgea Balanchina. Kasnije će u toj školi i osobno predavati, ali tada je bio samo učenik koji "guta" sve što mu Balanchine može pružiti. Oko 1943. godine, počeo se baviti koreografijom iz osobnih, istraživačkih motiva. Godine 1947., predaje moderni ples $u$ Balanchinovoj školi i iste godine stvara djelo "Godišnja doba", za baletnu družinu koja je bila pretečom "New York City Ballet”. Glazbu za "Godišnja doba” je skladao mladi skladatelj koji je radio s Cunninghamom od početka njegove koreografske karijere, John Cage. Upliv Cagea na Cunninghama i obratno, velik je i neprocjenjiv.

Jedan od zanimljivijih aspekata modernoga plesa, prije Cunninghama, bila je njegova ovisnost o konvencionalnoj glazbi. Tako se događalo da najavangardnija od svih scenskih vrsta, koristi, pa čak i naručuje, partiture koje su bez obzira na njihovu kakvoću izrazito konzervativnog oblika. Sa svojim pripremljenim glasovirima i nepripremljenim slušateljima, svojom elektronskom glazbom, svojim zen-budizmom, svojim „lakrdijama i ludorijama" i oporim humorom, Cage je dodao i nov element - ples. Osim toga je postavio Cunninghamovu trupu, od početka, $\mathrm{u}$ prve redove avangarde.

Ovdje se treba prisjetiti da se cijela povijest umjetnosti XX. stoljeća može promatrati kao „pokret k apstraktnom”. Glazba, slikarstvo, pa čak i verbalne umjetničke vrste kao što su književnost i kazalište, pokazuju iste nakane. Ali ples? Prvi put sam se susreo sa Merce Cunninghamom, 1966. godine u Londonu. Sjećam se da sam ga upitao što misli o apstraktnom plesu. Nasmijao se i uz grimasu rekao: „Sve što ljudi rade je ljudsko, prema tome apstraktni ples je nemoguć". Znao sam tada da je u pravu. Ali to mu nije smetalo da krene tim smjerom.

Cunningham naginje, u svojim metodama, k objektivnom pokretu, onom iz kojega su subjektivni elementi, kao što su naracija i emocija, izbačeni. Jednom zgodom mi je rekao: „Mene najprije zanima ono što ljudi rade. Obična gesta i stvaranje kontinuiteta ljudskih pokreta". Tom formulacijom je, mislim, izrečen cijeli princip „objektiv- 
nog plesa". To je ples i gesta, zbog samih sebe, $u$ autohtonoj afirmaciji.

A vi gledatelji, izvolite samo "unijeti” $u$ to što god hoćete. Jednom sam ga upitao o tome kakav je odnos između njegova stila i klasičnog baleta, prema kojemu on ima veliki i skoro „bolan” afinitet. Odgovorio mi je: „Ne trudim se stvarati stil. Stvari se jednostavno same događaju. Kada čovjek nastoji stvoriti stil, to često sliči svojevrsnom manirizmu, gubi se iskrenost. Za mene stvar postaje zanimljiva kada je neki pokret težak za izvođenje, ali ne zaboravite da postoji svega šest-sedam načina na koji se čovjekovo tijelo može kretati. Za moj rad vele često, da u izvjesnom smislu, podsjeća na klasičan balet. To dolazi, mislim, zbog toga što ja fizičku akciju smatram značajnom po samoj sebi. U mojem pristupu sve počinje od kralješnice. Potrebni su mi ,jaka i elastična leđa" i vrlo sam zainteresiran za ravnotežu. To je ono što mojim djelima daje klasičan prizvuk; $\mathrm{u}$ modernom plesu se pretežito nastoji na neuravnoteženim položajima, što predstavlja temeljnu razliku između modernog i klasičnog baleta. Cunningham je otvoren. On se služi modernim svijetom, jer je slučajno u njemu rođen. Odbacuje izraz avangarda. Za njega je elektronska glazba postojeća i kao takvoj joj treba dati prigodu uporabe. Za njega nema „bjelokosnih kula”, on sa nama dijeli „našu prljavštinu i naše patnje".

Stil Paula Taylora je posve drugačiji. Jedna od malih ironija plesa je, da je Cunningham, koji se zalaže za objektivnost, ponekad vrlo angažiran plesač, a da Taylor, lirski pjesnik plesa, ispada ponekad formalan i još češće, nekako, iznad ovozemaljskih stvari. Taylor je rođen, 1930. u Pittsburghu, a postao je plesačem jednom "greškom". U Collegu se bavio plivanjem, a slučaj je htio da je Martha Graham, predavala ples u jednoj školi koju je polazio. Martha je tada tražila muške plesače i uvjeravala Taylora da se pridruži njenoj trupi. U to je vrijeme Taylor želio studirati slikarstvo. Priča da je Marthi odmah „zapeo za oko”.

Vidjela ga je nespretna i kako se dobrohotno gega među njenim učenicima.

Rekla je jednom od asistenata da ga pozovu u trupu. „Kocka je bila bačena”. Uspjela ga je napokon pridobiti. Taylor je nastupao sa Martnom Graham i, kao i Cunningham, postao jednim od njenih najboljih plesača. Još dok je bio u njenoj trupi, potpao je, opet kao i Chunningham, pod Balanchinov upliv. Daleko je manje znano da se Taylor neko vrijeme zanio idejom da se pridruži
Balanchineu i moderni ples zamijeni klasičnim baletom. Kao većina modernih plesača njegova naraštaja, prošao je kroz stanovitu klasičnu obuku, pa taj prijelaz ne bi bio moguć.

Belanchine je bio fasciniran njegovim dugim i gipkim skokovima, dok se Taylor, sa svoje strane, divio Balanchineovoj "ekonomičnosti” koreografskog materijala. Ali je Taylor bio odviše neovisna duha. Nije se mogao pridružiti Balanchineu kao što nije mogao ostati niti kod Marthe Graham. Prvi Taylorovi koncerti su bili "divlji” dadaistički happening, iako je "njegov dadaizam” ostao u granicama striktnih kazališnih okvira. U tom razdoblju je stvorio svoja najpoznatija djela i postigao svoje glavne uspjehe. Danas se priča da je bio u stanju stajati oko dvadeset minuta, što je dakako, netočno, ali je uspio u jednom svojem djelu rađenom prema glazbi Johna Cagea, stajati, kao okamenjen, tri pune minute, što je podvig na sceni. Ta antiigra je toliko zbunila kritičara Louisa Horsta, da je u prikazu koncerta u listu „Dance Observer", umjesto prikaza, dao antiprikaz prazan stubac na stranici.

Bilo je još „dadaističkih majstorija”, poput plesa komponiranog prema magnetofonskom zapisu, koji najavljuje vrijeme, udarac u gong, označit će točno......", što je trajalo punih dvadeset minuta. Ali dok su takve stvari u podjednakoj mjeri, zabavljale i uzrujavale plesno-umjetničku javnost, za Taylora su one bile svrhovitije, jer su simbolizirale njegov protest prema Marthi Graham. Puno godina kasnije, $\mathrm{u}$ jednom pismu koje $\mathrm{mi}$ je poslao, evocirao je neke svoje ugodne uspomene iz života i tom zgodom naznačio: „U to sam vrijeme otkrio, na svoj način, nestilizirani pokret $\mathrm{i}$ nepomičnost. Postoji nešto što objedinjuje Cunninghama i Taylora! Martha Graham i moderni ples nastoje se razviti, uopćeno, na idejama o stvarima i ljudima. Većina tih djela je narativnog karaktera i skoro sve nose u sebi jedan literarni element.

Cunningham i Taylor su odlučili da je ples sam sebi cilj. Cunningham je želio „plesati kroz glazbu", služeći se glazbom kao potkom sredine. Konvencionalniji Taylor "pleše po glazbi” i spada među najmuzikalnije koreografe. Njegov ples je hladan, znalački i imaginativan. On je najklasičniji koreograf, jer sugerira klasične vrijednosti, proporcije i gracioznosti. Njegova koreografija je čak, po njegovim riječima, „čaranje” i smišljen pokušaj da se ples prikaže kao stil sličan akcionom slikarstvu. Međutim, ono što danas prožima Taylo- 
rovo djelo, je ozbiljno spokojstvo, jedna rijetka umjetnička vrlina. Ponekad se događa da Taylor stvori "grčevitu sliku suvremenog društva", kao što je slučaj sa Scudoramom ili djelom „From Sea to Shining Sea", u kojem daje jednu od veselo složenih plesnih-satira. Međutim, njegov „olimpijski stil" je danas ležeran i božanstven, što fascinira njegovu publiku. Njegovi radovi, "Aureole" i "Orbis", smiono postavljeni prema zadnjim Beethovenovim kvartetima, spadaju, kao i najbolji Cunninghamovi radovi, među velika djela američke plesno-umjetničke scene. Ironija sudbine je učinila da su i Cunningham i Taylor dva najpoznatija "siromaha” u svijetu. Oni su doživjeli potpun uspjeh na međunarodnom planu, koji ih je zacijelo učinio sretnima, ali ne i bogatima. Obojica su bili prinuđeni da pretežit dio vremena, iz financijskih razloga, provode na turnejama po inozemstvu. $\mathrm{U}$ Londonu, gdje njihove predstave imaju svoju stalnu i odanu publiku, obojica su imali priliku osjetiti divljanje mase, za razliku od „kulta ličnosti". I jedan i drugi su dali više predstava u Londonu nego u New Yorku. Nakon velikog uspjeha i potpore svijeta, sustiglo ih je i priznanje u domovini, Americi. Njihove dvije plesno-umjetničke trupe su sastavni dio američke kulture i po mnogo čemu su "putokaz američkih umjetnosti”, pa su postali među najživljima i najuzbudljivijim predstavnicima koje je američki plesni teatar ikada imao. Oni su tvorcima i svjedocima velike ekspanzije plesne umjetnosti $u$ Americi šezdesetih godina. Početak sedamdesetih godina, donio je New Yorku izazovnu prigodu da odjednom ima četiri velike i utjecajne plesno-umjetničke trupe. Glavni je uzrok što je ples doživio taj novi polet, $\mathrm{u}$ tome što je nova "društvena klima”, kako je to zapazio Macuhan, vizualno orijentirana. U takvim uvjetima, ples i film imaju mnogo prednosti nad „ostalom konkurencijom" i to su nedvojbeno umjetničke vrste koje tada nedvojbeno privlače mladež.

Cunningham i Taylor, kao da su bili $\mathrm{u}$ klopci. Taylora su prokazivali da puni kuću plesom, protiv svih pravila, a nakon uspjeha njegove „Brooklinske sezone”, i Cunningham je postao "subjekt sličnih prigovora". To je uostalom bilo predvidljivo. Zapravo je to nesporan znak da su obojica ovih umjetnika i stvaralaca, htjeli to ili ne, uveli nova pravila u umjetnost plesa. U njima američki moderni ples pogrešno nazvan „modernim baletom nalazi svoje prirodne vođe suglasne vremenu i prostoru dinamičke civilizacije novog kontinenta $\mathrm{u}$ „drugom poluvremenu ovog stoljeća".

Možda je to razdoblje početka druge polovice stoljeća bilo slično onome što ga je početkom stoljeća u Parizu bio stvarao, gotovo revolucionarnim poletom i zanosom, istaknuti novinar i impresario, Sergej Djagiljev (1872. - 1929.).

Balet kao glazbeno-scenska vrsta ima dva bitna elementa: umjetnički ples i glazbu u tijesnoj međusobnoj svezi. Plesom se na sceni razvija dramski sadržaj, koji se zbiva „nijemim jezikom” retorikom tijela.

Porijeklo baleta, kako je rečeno, otkrivamo u primitivnim magijskim obredima, kulturnim obredima starih civilizacija, grčko-antičkoj tragediji i komediji, srednjovjekovnim prikazanjima, dvorskim plesovima, plesovima uličnih plesača, pjevača i zabavljača u razdoblju srednjega vijeka, te $\mathrm{u}$ folklornim plesovima raznih naroda, kroz povijest čovječanstva. Najranije tragove baleta, kao umjetničkog plesa, nalazimo $\mathrm{u}$ drugoj polovici XVI. stoljeća. Godine 1570., de Baif, osniva Akademiju glazbe i poezije, s nakanom da potpuno afirmira baštinu antičke-grčke tragedije.

Uz glazbu i poeziju, pokazala se nužnom i umjetnost plesa, na predstavama Akademije, pa nastaje balet mesure. Krajem stoljeća Baif i Ronsard, stvaraju na dvoru dinastije Valois, Ballet de court (Dvorski balet). Predstavom nazvanom „Le Ballet comique de la reine", (1581.) (Komični kraljevski balet), u kojoj je ostvarena sinteza plesa, glazbe, pantomime, raskošnog dekora i kostima, počela je $u$ vrijeme duha europske feudalne aristokracije, i organizacije dvorskih baleta, povijest klasičnoga baleta. Ulogu koreografa koji se isprva zvao „ordonnance geometrique”, preuzeo je guslač dvorskog orkestra Baltazar de Beaujoyeux, a glazbu je napisao Lambert D' Beaulieu. Premijera je održana u Bourbonskoj palači u Parizu, pred više tisuća uzvanika. Stajala je oko tri milijuna zlatnih franaka. Ovom predstavom i njenim raskošnim stilom, su stvoreni temelji baletne umjetnosti apsolutističkih monarhija u Zapadnoj Europi, koja svoj vrhunac dostiže za vladanja Louisa XIV., sredinom XVIII. stoljeća. Tako je skladatelj J. B. Lully, dominirao glazbenim životom Francuske. Lully, Beauchanos i Peciurt, osnivaju, 1661. godine, prvu baletnu školu, Akademie Royale de Danse (Kraljevska akademija plesa) u kojoj se proučavaju baletni pokreti, te određuju stroga pravila plesa kao umjetničke vrste. Lully je bio vrstan plesač i koreograf, pa je ostvario mo- 
numentalni projekt Ballet Royale de la Nuit (Noćni kraljevski balet), 1663. godine, kojim se završava razdoblje "dvorskih baleta", pa ova umjetnost „prelazi” u opere koje Lully sklada, objedinjujući i obogaćujući sve njene scenskoglazbene elemente. Na Lullyev „strogi stil”, u baletnoj umjetnosti, u likovnom aspektu geometrizirano-dekorativnom, nastaje reakcija iz "plebejskih izvora" u novonastaloj vrsti „baletne opere” nazvane Ballet des quatre parties du monde (Balet sa četiri strane svijeta), u kojemu se zamjećuju folklorni i egzotični elementi.

Baletni ples se, potom, uvodi u talijansku operu-seriju, a nalazimo ga i u razvijenim oblicima komične opere. Balet, najčešće lociran u II. čin djela, postaje tradicionalnim $\mathrm{u}$ talijanskim i francuskim operama XVII. i XVIII. stoljeća. Takvu shemu su izmijenili operni skladatelji XIX. stoljeća. Šaroliki i čulno izazovni baletni spektakl bio je često jedini razlog opstanka opernoga djela u programu kazališta na dvorima aristokracije i kraljeva. Jedan od razloga lociranosti „baletnog umetka" u II. čin radnje, je i želja da ih vidi publika koja je „otmjeno" zakašnjavla na predstavu (noblesse oblige).

U izražajno-estetskom smislu, francuski dvorski balet je naglašeno dekorativan, što znači da on ne obrađuje neku dramsku radnju, niti je emocionalno usmjeren. Prema strogoj shemi, niže se više „brojeva” i pred publikom nastaje raskošni spektakl, čiji je cilj, zabaviti gledateljstvo.

Takvim običajima se opire, 1760. godine plesač i koreograf Noverre, zahtjevom da plesači skinu maske, koje su prema uvriježenim pravilima doba, nosili. Zalaže se za izražajnije pokrete. Ove ideje su pridonijele reformi baletne umjetnosti $u$ drugoj polovici XVIII stoljeća i njenom procvatu u epohi rokokoa i klasike. Opere Glucka, Mozarta, Beethovena, svjedoče o tome. Drugi značaini reformator baleta je Salvatore Vigano (1769.-1821.) koreograf Beethovenova baleta "Stvaranje Prometeja", koji je, štujući zakone prostora na sceni, uveo u tradiciju klasičnog baleta iz doba Lullya, veću izražajnost, povezujući klasični ples sa mimikom i pantomimom. U suradnji sa teoretičarom Karlom Blasisom, Vigano napokon utemeljuje kanone klasičnoga baleta koji opstoje, do danas.

U romantičnom XIX. stoljeću, baletna umjetnost doživljava sadržajnu i formalnu preobrazbu, premda se neki elementi klasičnoga plesa ne mijenjaju, čak se i razvijaju poput plesa na vrhovima prstiju koji je prvi put primijenila Maria
Taglioni (1804.-1884.), jedna od najvećih umjetnica svoga doba. Balet i nadalje ostaje sastavnim dijelom opere, ali se u epohi romantizma budi veće zanimanje za njega kao samostalnom glazbenoscenskom vrstom. Skladatelji, poput Delibesa, Čajkovskoga, Debussya i drugih, posvećuju mu u svojim opusima, posebnu pozornost. Djela ovih majstora omogućavaju ekspresivniju koreografiju. Ukupno gledano $\mathrm{u}$ epohi romantizma baletna umjetnost gubi pomalo na stupnju izražajnosti, jer se pozornost posvećuje tehničko-izvedbenom virtuozitetu. To je vrijeme stvorilo i neke od legendi u baletnoj umjetnosti: Didelot, Petipe, Cecchetti, predstavnici su baletnog akademizma tzv. „bijelog baleta" (zbog bijelih kostima koji su se pretežito nosili na sceni).

U XX. stoljeću se opet aktualizira pitanje reforme baleta, na poticaj emocionalne interpretacije plesnih verzija američke plesačice Isadore Duncan (1878.1927.), koja pokazuje cipelu i inspirira se klasičnom likovnom umjetnošću (važno slikarstvo) koja prikazuje plesače u pokretu. „U plesu tijelo treba biti slobodno, ples mora dati novo osjećanje tijela i života", govorila je Miss Duncan. Njena inicijativa pospješuje stil tzv. modernog plesa, čiji je promicatelj Jacque Dalcrosse, koji je u suvremenoj umjetnosti protuteža klasičnom baletu. Moderni ples oslobađa pokrete tijela, njeguje elemente pantomime i mimike, skida baletne cipele, utemeljuje širi raspon plesno-scenske izražajnosti. Novi veliki procvat klasičnog baleta slijedi tek osnivanjem ansambla Ballet russes (Ruski baleti), 1909. godine u Parizu, poticajem Djagiljeva i njegova kruga umjetnika stasalih $\mathrm{u}$ petrogradskom Mariinskom teatru. $\mathrm{Na}-$ pustivši studij prava u Petrogradu, genijalni organizator kako je iskustvo pokazalo, Sergej Djagiljev se nastanio u Parizu isprva kao novinar. Organiziravši u Parizu praizvedbu glazbene drame Musorgskog "Boris Godunov", Djagiljev počinje stvarati uvjete za reformu tradicionalnog ruskog baleta, slijedeći nakane svoje generacije izražene još krajem XIX. stoljeća. Prijateljstvo s koreografom Mihajlom Fokinom (1880.-1942.) nuka Djagiljeva da osnuje umjetničku trupu Ruski baleti (Ballet russes) u Parizu.

Ansambl okuplja, uz Fokina, i plesače Anu Pavlovu, Njižinskog, Lifara ..., a tom umjetničkom krugu prilaze i vrsni skladatelji, slikari, književnici. 
Svi su jednodušni $\mathrm{u}$ pristupu potrebnim inovacijama u plesnoj umjetnosti. Skladatelji Stravinski, Debussy, Ravel, Respighi, Prokofjev, Satie, Honegger, Milhaud, slikari i prigodni scenografi Picasso, Braque, Derain, Baxt, de Chirico, ostvarili su niz remek-djela baletne umjetnosti, pretežito $u$ koreografiji Fokina, a potom i Masina, Njižins$\operatorname{kog} . .$.

U izvođenju ovog proslavljenog ansambla doživjela su mnoga najveća djela baletne literature svoje praizvedbe: „Žar ptica”, „Petruška”, „Pulcinella”, „Praznik proljeća”, „Svadba”, od Stravinskog, „Trorogj šešir", de Falle, „Fantastična kutija”, Rosini-Respighija, "Silphide”, Chopina, "Seherezada", Rimski-Korsakova. Ansambl Ruski baleti, je razvijao svoj upliv na principima usavršavanja iskustva klasičnoga plesa, njegove simbolike, sa naglašenom težnjom za slobodom izraza tijela $u$ okviru vladajućih estetskih mjerila vremena.

Ovaj veliki umjetnički krug, oplođuje scenu ansambla Ruski Baleti, novim idejama i scenskim rješenjima za umjetničke projekte, koji su gotovo provokativni za ukus i navike tadašnje pariške kazališno-umjetničke javnosti.

Djela izvedena na sceni ansambla Ruski Baleti u Parizu, a kasnije i u Monte Carlu, u svom kasnijem scenskom životu su doživljavala mnoge inovacije, prilagodbom novim etapama plesnoumjetničke estetike i njoj primjerene dramaturgije, kroz sve vrijeme do danas.

Ta inventivna smionost Djagiljeva, koji je žestoko pokrenuo umjetnički Pariz, od prvih godina stoljeća, bila je presudna za duh i pojave $u$ umjetnosti, napose scenskoj, svih kasnijih godina pa i desetljeća, u umjetničkom životu i načinima rada umjetničkog Pariza.

Živjeti i stvarati u francuskoj metropoli, značilo je imati smionosti a i mogućnosti istraživanja, eksperimentiranja i otkrivanja novih $\mathrm{i}$ sve boljih vrsta i oblika izraza i prezentacije osnovne ideje svakog planiranog i ostvarenog umjetničkog projekta.

POKRET U FUNKCIJI DRAMSKOSCENSKOG ZBIVANJA

Uloge u HNK u Zagrebu

Grof Albrecht - Giselle Adolphea Adama;
Mirko - Đavo u selu, Frana Lhotke, k. Pia i Pino Mlakar; Princ - Orašar, P.I.Čajkovski, k. Waczlaw Orlykowski;

Princ Sigfried - Labuđe jezero, P.I. Čajkovskog;

Princ Désiré - Trnoružica, P.I.Čajkovskog, k. Waczlaw Orlykowski;

Momak - Carmina burana, k. Drago Boldin;

Franz - Coppélia Léa Delibesa, k. Ivica Sertić;

Solo par - Proljeće, Solo par - Ljeto, Solo par - Zima Četiri godišnja doba

Mladić - Chopiniana, k. Iraida Lukašova;

Mandarin - Čudesni mandarin Bele Bartoka, k. Milko Šparemblek;

Basil - Don Quijote Ludwiga Minkusa, k. Dinko Bogdanić;

Mefisto - Johannes Faust passion Milka Šparembleka, k. Milko Šparemblek;

Romeo - Romeo i Julija S.S. Prokofjeva, k. Dinko Bogdanić;

Apolon - Apolon Muzaget/ Koreografije Georgea Balanchinea;

Soba/ Koreografije Renata Zanelle,

Adagietto/ Koreografije Renata Zanelle,

Solo par - Prazno mjesto / Koreografije Renata Zanelle;

James - La S yilphide H.S. Lǿvenskjolda, k. Norman Dixon;

Žigolo - Coppélia na Montmartreu Léa Delibesa-Yourija Vàmosa, k. Youri Vàmosa;

Putnik, Dijalog - Pjesme ljubavi i smrti Gustava Mahelra-Milka Šparembleka, k. Milko Šparemblek;

Adem i Hava - Danse macabre Marjana Nećaka-Staše Zurovca, k. Staša Zurovac;

Sinfonia da requiem, g. Benjamin Britten, k. Vasco Wellenkamp;

Armandov otac - Dama s kamelijama A. Dumasa sinaC.-Davisa-D.Deanea, k. Derek Deane,

Don Quijote - Don Quijote Ludwiga Minkusa, k. Patrick Armand,

L'Amour eternel/Koreolabos, glazba Giulio Caccini, kor. Ilir Kerni

Lovački oficir - Gospoda Glembajevi, kor. i red. Leo Mujić, 30. 5. 2017.

Constantin Christhomanos - Elizabeta Austrijska - Sissi, kor. i red. Patrice Bart, 27. 3. 2018.

Uloge izvan HNK u Zagrebu

Nastupao je u Sloveniji, BiH, Albaniji, Grčkoj, Turskoj, Češkoj, Mađarskoj, Francuskoj, Njemačkoj, Nizozemskoj, Finskoj, Švedskoj, Kini, Velikoj Britaniji, Belgiji, Španjolskoj, Portugalu, Italiji, Meksiku, Japanu, Macaou, Hong Kongu. 
VERTICAL OF LIFE FOR A LIFE ON STAGE

Ilir Kerni, principal dancer at Croatian National Theatre in Zagreb

\author{
Slobodan Elezović \\ Croatian Communication Association, Zagreb, Croatia
}

\begin{abstract}
At the age of 60 , after a career of full four decades in the ballet arts as the most complex and multi-layered form of performance arts, the entirety of Mr. Ilir Kerni's achievements as an author of global renown is the subject of systematic approach in the monograph calling for methodical and meticulous research of the creative life and work of a special man and his worldview, including his outstanding aesthetic focus in performance arts as his core preoccupation, with a range of styles and potentials for a successful start and for guaranteed supreme accomplishments in choreographic and educational work and in any other role, considering his debut genre, the freshness and the completeness of his élan, enthusiasm and capacity as the guarantees of the highest reaches in international presentation of his creations on the global scene and at the most renowned ballet arts centres. The monograph is merely 'an indicative symbol' and the expression of value highlights that, as an example of the art of full immersion in one's chosen career path, become a supreme starting point for the greatest creations and for a place among the most elite Croatian and international authors.
\end{abstract}

Key words

Ilir Kerni, ballet, art 